\title{
Ronald Woods: A szociális munka saját életutamon át a társadalmi változások tükrében
}

az ELTE Szociális Munka Tanszékén 2019. október 10-én elhangzott elöadás szerkesztett változata

Megtiszteltetés a számomra, hogy előadást tarthatok az ELTE Szociális Munka Tanszékén. Elnézést a magyarnyelv-használatomért, van, amikor mint egy pillangó keresem az „édes szót” vagy kifejezést, és nem mindig találom a megfelelő virágot. Máskor a helyes ragozást keresgélem, látszik az is, amikor mint a sikeres aranyásó, megtalálom az aranyat és olyan helyzetek is előfordulnak, amikor teljesen eltévedek és úgy vagyok, mint egy hajó az üres tengeren, és újra kell kezdeni az egészet. Ráadásul dél-afrikai kiejtésmódom van, magyarul beszélek dél-afrikai akcentussal. De remélem, hogy az előadás izgalmas lesz és tiszta szívemből azt is remélem, hogy tanulságos, hasznos és gondolatébresztő is lesz.

Szóval dél-afrikai származású vagyok, az elődeim több mint 300 éve Afrika földjén élnek. Nekem nincs európai rokonságom. A családom kétnyelvü. Az iskolában csak az utolsó évben döntöttem el, hogy szociális munkát tanulok: egyrészt azt éreztem, hogy így segíthetek más embereknek, például olvastam a csoportmunkáról, és mint módszert nagyon érdekesnek tartottam. Volt némi családon belüli tapasztalatom is, föleg arról, hogy mit jelent, ha segítségre van szüksége valakinek, pl. az apukám alkoholista szenvedélybeteg volt, az anyukám egyik öccse értelmi fogyatékos volt, ő volt a fő gondozója és láttam, hogy milyen hatással van ez rá.

Amikor 15-16 éves voltam, rájöttem, hogy baj van az országomban, valami nem stimmel a politikában, a szociális és közéleti területen. Egyfajta düh, harag ébredt fel bennem, és mivel nem tudtam, hogyan lehet ezt kifejezni, az a meggyőződés alakult bennem, hogy igazságtalanság van Dél-Afrikában, és hogy alapvetően a rasszizmus ellen kellene harcolni. Ehhez nem volt példakép a családon belül, így ez egy magányos út volt a számomra. Bár a nagyapámtól emberi méltóságot és bölcsességet tanultam, például azt, hogyan kell becsületesen élni és azt, hogy fontos sok mindent megkérdőjelezni. Végül is lényeges volt a döntésemben az is, hogy ösztöndíjat lehetett szerezni a szociálismunkás-képzésre, és így eltávolodtam az eredetileg tervezett művészeti pályától. Az csak egy álom volt, és oda nem volt lehetőségem ösztöndíjat sem szerezni.

\section{Milyen volt a szociálismunkás-képzés Dél-Afrikában?}

A szociális munka már a húszas-harmincas évek óta erős szakmává vált Dél-Afrikában. Tisztelt, bár nem rangos/nagynevü szakma volt. Fontos szerepe volt különféle társadalmi, szociálpolitikai területen, és világszintű volt a szakmai képzés. A University of Witwatersrandnek (Wits) volt az egyik legrangosabb szociális munka tanszéke az országban, és hálás voltam, hogy engem befogadtak hallgatóként. Így Bloemfonteinből Johannesburgba költöztem, ott folytattam az életemet. Pont 40 évvel ezelőtt (1979-ben) kezdtem az egyetemi 
tanulmányaimat. Annyi év után, még mindig azt hiszem, hogy magas szintű szakmai képzés folyt ott. Tényleg hálás vagyok érte.

A Wits Egyetem erősen szabadgondolkodású volt, sőt híres arról, hogy ellenállt az apartheid, faji elkülönítésre épülő rasszista rendszernek. Dél-Afrikában legalább érinthetetlen volt az akadémiai szabadság sok minden más ellenére. Ez az egyetem volt Nelson Mandela alma matere is. A szociálismunkás-képzés tanterve kifejezetten a társadalmi igazságosság, egyenlőség elvei alapján épült fel. A szociológia tanszéken erős hatása volt a marxizmusnak, és mivel a szociológiát a szociális munka mellett fó irányként választottam, ez hatással volt a gondolkodásomra, azaz mind a klasszikus marxizmus, mind a hatvanas évektől kezdődő új baloldali gondolkodás. Rengeteget olvastam, vitatkoztam. Megtanultam, hogy az ember és a társadalom közti kölcsönhatásban találja meg a szociális munka a maga szerepét a különböző társadalomtudományok sorában, és megtanultam, hogy szoros kapcsolat van a szociális munka és a szociálpolitika között. Vegyes terepgyakorlat volt a négy év alatt: közösségi munka egy hátrányos helyzetü negyedben; értelmi fogyatékossággal élőkkel csoportmunka; esetmunka azokkal, akik a börtönből visszalépnek a közösségi életbe; és a negyedik évben pedig iskolai szociális munka.

\section{Kilépés a külvilágba}

Dél-Afrikából 1983-ban számkivetésbe mentem a szomszéd, az akkor függetlenné vált Zimbabwébe. Indítékaim: 1976-tól a helyzet fokozatosan komolyabbá, súlyosabbá vált, DélAfrika háborúban állt a szomszéd országaival, valamint saját magával (de facto polgárháború). Minden egyes embernek el kellett döntenie, hogy hol áll. Feleségem sajnos autóbalesetben életét vesztette, 22 éves voltam és úgy döntöttem, hogy nincs amiért maradjak az országban. A szociális munka BA szak befejezése után besoroztak. Minden fehér férfinak kötelező volt két évet szolgálnia. Megszöktem a katonaságtól, azaz büncselekményt követtem el, és nem tudtam visszamenni a szülőföldemre addig, amíg nem változott meg a rendszer. A zimbabwei hatóság végül is nem adott engedélyt, hogy ott maradhassak, így az ENSZ Menekültsegély Alapítvány támogatásával egy év után, azaz 1984 közepén Ausztráliába Új-Dél-Wales államba kerültem. Erre nem számítottam!

Az első szociális munka állást egy szenvedélybeteg-szolgálat telefonos segítő központban kaptam, melyben feladatom a kliensek szolgáltatásokhoz történő delegálása volt. Közben más munkát kerestem, és három hónap múlva az Ausztrál Zsidó Családsegítő Központnál (Austral Jewis Family Welfare Society) Sydney-ben sikerült állást kapni, ahol föleg az értelmileg sérült kliensekkel és azok családjaival dolgoztam. Volt némi tapasztalatom ezen a területen a korábbi egyetemi terepgyakorlatom kapcsán. Majd más területeken is dolgoztam: esetmunka, idősekkel való szociális munka, közösségi projektek. Nagyon jó volt ez a három év számomra, rájöttem, hogy eredményesen tudok dolgozni a közvetlen szociális munka módszerekkel, mint esetmunka, csoportmunka, közösségi munka és azon kívül a közvetett módszerekkel is, azaz adminisztráció, szupervízió és kutatás. Megírtam az első folyóiratcikkemet az ausztrál szociális munka szakfolyóiratban - Social Group Work for Social Change (1987). 


\section{Az ausztrál szociális munka és a szociálpolitika a '80-as években}

Ausztráliában akkor még jól müködött a jóléti állam. Erős volt a szociális szolgáltató rendszer, és különböző föiskolai képzések voltak, mert kevés volt az az állás, ahol kifejezetten csak egyetemi diplomával lehetett dolgozni, föleg az egészségügyi területen. Úgy éreztem, hogy Ausztráliában a dél-afrikai helyzettel szembeállítva a szakma inkább egészségügyi/rehabilitáció szemléletű szakmává vált. A közösségi munkát és a radikális közösségi akcióra épülő munkát Ausztráliában más végzettségü szakemberek végezték, kifejezetten közösségi dolgozók (community workers), akiknek nem volt kötelező bejegyeztetni magukat a szakmai egyesülethez. Nem volt a szakmai tevékenységeket és szerepeket pontosan meghatározó szociálismunka-törvény, mint Dél-Afrikában.

Jellemző volt, hogy a 80-as évek folyamán megerösödött a neoliberalizmus hatása minden irányból: gyengébb lett a közösségi élet, a szociálpolitika és a jóléti ellátás, erősebb lett a privatizáció és az individualizmus. Világszerte ez volt a tendencia és most, 30 év múlva, pontosan lehet látni, mi lett ennek a következménye. Ausztrál állampolgárságot szereztem, és eldöntöttem, hogy közelebb szeretnék lenni Dél-Afrikához, ahol - ez már 1987-ben volt megerösödött az apartheid elleni harc. Az eredeti tervem szerint Európán át akartam visszamenni Zimbabwébe ezzel a semleges ausztrál útlevéllel.

\section{Magyarország}

Így teljesen véletlenül jött az életembe Magyarország! 1989-től itt éltem 4 évig. Mint szokásos, elöre nem látható történéseknek az volt a következménye, hogy például az angol nyelvtanítás kapcsán találkoztam Ritoók Magdolnával. Ö bemutatott Hegyesi Gábornak, Talyigás Katalinnak, Ferge Zsuzsának, sőt annak a szakmai körnek, amely épp azzal a feladattal küzdött, hogy miképpen legyen Magyarországon szociálismunkás-képzés.

A képzettségem és a munkatapasztalatom hasznosnak bizonyult ezen törekvésben, és ekkor kezdődött az életem egyik legizgalmasabb kihívása. Öszintén mondhatom, hogy ez a karrierem csúcspontja volt. Mindenki nem csupán kolléga volt, hanem barát is. Most a 30. évfordulón biztos, hogy sok szó esik majd sok mindenről a szekszárdi találkozón és konferencián. ${ }^{1}$ Az én közremüködésem annak idején az volt, hogy a szociálismunkás-képzés koncepcióját, célját, feladatait és leendő tanterveit átgondoljuk, különösen a terepgyakorlatot, és utóbbi tekintetében a Budapest VII. kerületi Esély Családsegítő Központtal együttmüködve. Feladatunk volt még a képzőhálózat létrehozása, mindenhova utaztunk Soprontól Debrecenig. Fantasztikus volt. Tanársegéd voltam az ELTE Szociális Munka Tanszéken, aminek keretében könyvet is írtunk: A szociális munka elmélete és gyakorlata című könyvet, jó volt hallani nemrég egy hallgatótól, hogy még mindig használják.

\footnotetext{
1 „Szekszárdi szociálismunkás-képzés 30”. Találkozó és szakmai konferencia, PTE KPVK - Iskolaszövetség MTA SZTB SZMA, 2019. október 11.
} 
Benyomásaim: a modern társadalomban fontos, sőt nélkülözhetetlen szerepe van a szociálismunka-szakmának, hiába állítják sokan, hogy nincs szükség rá. A politika nagymértékben befolyásol minket abban, hogy hogyan néz ki a képzés egésze, abban a föleg terepen folyó gyakorlatok, másfelől pedig az elmélet, de szerepe van a történelemnek, a kultúrának és a véletleneknek is. A hatalom szinte mindig azt akarja, hogy a szakma inkább csak akkor jelenjen meg, amikor már kialakult a probléma, nem megelözni akarja azokat.

\section{Vissza Dél-Afrikába}

Ahogy mindenki tudja, az 1989., 1990. és az 1991. év rendkívül eseménydús volt, szinte világszerte. Az ember úgy érezhette, hogy az emberiség nagy lépéssel haladt elöre, és hogy egy tiszteletteljes, együttmüködőképes, békésebb világot lehet építeni. Izgalmas időszak volt.

Rendszerváltás történt Dél-Afrikában is, egy általános közkegyelem alapján lett jogom akkor visszamenni az anyaországomba. Nem volt könnyü ez a döntés, mert boldog voltam Magyarországon. De kiszabadult Nelson Mandela, nagy optimizmus volt az ország jövőjéért, és részt akartam venni az úgynevezett Új Dél-Afrika változataiban. A szivárványnép.

Nagy szerencsém volt, hogy állást kaptam a Wits Egyetemen, az alma materemben. Összesen 7 évet dolgoztam a Szociális Munka Tanszéken és így megint Johannesburgban éltem. Izgalmas volt a feladatunk, hogy készítsünk fel olyan szociális munkásokat, akik közvetlen és fontos szereppel tudnának részt venni a rendszerváltás utáni gyorsan fejlődő szociálpolitikában. 1992től új elképzeléssel úgy fogalmazták meg a dél-afrikai szociálpolitikát, hogy az „developmental social welfare". Röviden azt jelenti, hogy fontos a szociális szolgáltatás az állampolgárok (a nép) fejlesztésében, és elfogadva, hogy a szociális szakmának szerepe van a demokratizálásban, az újjáépítés szervezésében, az emberi jogok előmozdításában. Szinte minden társadalmi és közéleti területen meg kellett küzdeni, tudniillik óriási probléma volt többi között a szegénység és a hajléktalanság, a bünözés, a nők elleni erőszak, a szenvedélybetegség, a fogyatékosság stb. És jelen volt egy katasztrofális kihívás, a HIV/AIDS, erről majd később. Ragyogó szociális munka hallgatóink voltak, és hálás voltam, hogy a karrierjük kezdetén ott lehetek.

Közben befejeztem a szociális munka MA szakot is, szakdolgozatom címe: „An Appraisal of Social Work on the Basis of its Relationship to Human Sexuality" volt. Nagy lelkesedéssel belevetettem magam a szociális munka kutatásába, rájöttem, hogy nagyon tetszik nekem. És miért éppen ez a téma? A magyarországi tapasztalataim alapján már a fejemben volt a kérdés, hogy tulajdonképpen mi is az, hogy szociális munka. Mi a különbség a szociális munka és más társadalomtudományi szakmák között, azaz mi határozható meg pontosan a mi szakmánkban? Saját kutatói érdeklődésem a szexualitással volt kapcsolatos: a nemiség és szexualitás kérdése, így a HIV kapcsán is, azazhogy miképpen jelenik meg. Az volt az álláspontom, hogy a szakmának szerepe van a humán szexualitás széles kérdésében, mindezt meg kellett határozni kutatások segítségével. A szociális munka elméleti és etikai elvei mentén különösen hasznosak azok a modellek, amelyek előtérbe helyezik az ember és a környezet közti kölcsönhatást, és úgy éreztem, fontos, hogy tovább fejlődjön a szakma ezen a területen is, különösen a HIV/AIDS kezelésének kérdésében. Dél-Afrika volt a világon az egyik legérintettebb ország, a 
népességnek több mint 20\%-a teljesen fertőzött volt. A gyors urbanizáció miatt egyre súlyosabb lett a helyzet, számos úgynevezett AIDS-árva élt az országban és a probléma csak nőtt. Azt javasoltam, hogy hangsúlyosan kell foglalkozni a nemiés szexuális kérdéssel a szociálismunkás-képzésben.

Alig fejeztem be a diplomamunkámat, amikor egy új pályán találtam magam. 1996 fontos év volt számomra, mert akkor teljesen nyilvánvalóvá vált, hogy a Homo sapiensnek kétségtelenül káros befolyása van az ökorendszerre, és ezzel az emberiség saját jövőjét fenyegetjük. A nyolcvanas évek elejétől fontosnak tartottam bővíteni a humánökológiai szemléletet, hogy a szakmának fontos a természettel is foglalkozni, amitől az egyéni és a közösségi túlélés teljes mértékben függ. Erről is elkezdtem írni és előadásokat tartani különböző szociálismunkakonferenciákon. Ez az ún. zöld gondolkodás a saját életemben is meghatározó volt, és egyre inkább úgy éreztem, hogy vidéken élnék szívesebben. Nem volt könnyü az egyetemtől elbúcsúzni. Egy kis városba, Barbertonba kerültem, és egy társsal kertészcentrumot nyitottunk. Viszont nem voltam képes teljesen a szakmától elszökni. Találkoztam egy nagyon helyes asszonnyal a kisvárosban, aki önkéntesként dolgozott egy pulmonológiai kórházban. Bekapcsolódtam a munkájába, és végül részfoglalkozást kaptam a kórházban azzal a feladattal, hogy a szociális munka tevékenységet építsem be a kórház szolgáltatásaiba. A helyzet a HIVfertőzés miatt egyre fokozódott, a tuberkulózis jelentős probléma volt, mégpedig egy nagyon veszélyes, a gyógyszereknek is ellenálló tbc, és amelyet csak nehezen lehetett kezelni. Elég nagy önkéntes stáb jött össze, és ennek képzését és szupervízióját láttam el. A stáb fô feladata az volt, hogy házról házra kellett járni és személyesen kellett foglalkozni a tbc-fertőzött emberekkel. Tájékoztatást adni, támogatni és biztosítani, hogy a kliens minden nap 6 hónapon át pontosan szedje a gyógyszert. Természetesen én is sokszor mentem lakásokba, és személyesen dolgoztam a kórházban fekvő betegekkel is. Gyakran azt kellett mondanom valakinek, hogy a tbc-n kívül HIV-pozitív is. Sokan haltak meg egyik napról a másikra. Iszonyatos volt a helyzet. És közben mit csinált értük az új dél-afrikai kormány?

Azt a hamis sztorit reklámozta és terjesztette, hogy nem létezik a HIV és hogy az AIDS a szegénységből adódik, és elég, ha a beteg jó táplálékot kap, mondjuk fokhagymát és répát. Rémes volt. Amikor azt láttam, hogy az országom egypártrendszerré válik, hogy a rendszerváltás csupán azt jelentette, hogy az egyik elit csoport helyett egy új elit réteg kerül hatalomra. A politikusok valójában nem tesznek semmit a fejlődésért, csak azért lépnek a kormányba, hogy ellophassák a közpénzt, a szemem előtt a kleptokrácia egyre nagyobb méreteket öltött, és közben az lett a fö téma, hogy akik fehérek, azok jelentik az igazi problémát, és hogy persze én is fehér vagyok, súlyos kiábrándultság szakadt rám, és nem tudtam ettől az érzéstől szabadulni. Eldöntöttem, hogy másodszor elhagyom a szülőhazámat és 2001-ben ismét visszakerültem Magyarországra.

\section{Kiábrándultság és azon túl}

Csak egy évig maradhattam Magyarországon, föleg az International House-ban dolgoztam nyelvtanárként. Természetesen továbbra is dolgoztam a szociális munka és a szociálpolitika területein dolgozó kollégáimmal, főleg Hegyesiné Orsós Évával az idősellátás területén. Azt 
lehetett látni, hogy már jelentős előnyöket hozott a leendő európai uniós tagság, így például közremüködtünk az EU-s Minority elderly care címü projektben.

2002-ben véget ért a vándorló életem és végleg vissza kellett térnem Ausztráliába, ahol jelenleg is állampolgár vagyok. Dolgoztam itt-ott különböző helyeken, de sokszor voltam munkanélküli is. Újra értelmi fogyatékos, valamint a HIV területén nonprofit szervezetekben dolgoztam. Nagyon erőssé vált a neoliberalizmus és a privatizáció, így még gyengébb lett a szociális munka szerepe a társadalomban. A közösségi szociális munka szinte megszünt, így nehéz volt beilleszkednem az ausztrál közéletbe. Pocsék időszak volt, de túléltem és lassan, mondjuk 2008-tól lettem derűs újból. Tanácsadási konzultánsként szerencsésen elkezdtem szervezni egy cég munkaprojektjeit. Minél kisebb és gyengébb lett az állam, annál erősebb és befolyásosabb lett a kiszervezés és versenytárgyalás. Ez a vállalat - Urbis - versenytárgyalás alapján megnyert különböző munkákat, főleg kutatásokat állami szervezetek számára. Rájöttem, hogy különleges képességeim vannak az új világban, azazhogy alapvetően generalista vagyok, így széles témákkal tudok foglalkozni. Jól tudok elméleti és gyakorlati kérdésekben mozogni, a szociálpolitikai kérdéseket összefogni, szintetizálni úgy, hogy ez hasznosulni tudjon. Szeretem a kutatást, az írást és különösen a szakirodalmi áttekintések készítését. Számos projektben közremüködtem, és néhány publikációm is született. Profi lettem a versenytárgyalásban, ezek szerint lenne jövőm a globalizációban!

Majd 2013-tól kezdtem dolgozni a University of Technology Sidney-ben, mégpedig az Önkormányzattan Tanszéken, ami az egyetlen Ausztráliában. Kutatás, képzés, publikálás a munkám, például a közigazgatásról, a decentralizációról, vagy az önkormányzat kapacitásépítése, önkormányzat pénzforrásai témákban. Három évvel ezelőtt teljesen elfáradtam a zsúfolt városi élettől, és kiköltöztem egy közösségi tanyára, ahol most is élek. Az egyetem mellett egy HIV-szervezetnél is dolgozom vállalkozóként.

Végül mit is gondolok a szociális munkáról? A legfontosabb kérdés ma a szociális szakmában az, hogy mi is a teendő a globális klímaváltozás kapcsán.

Szerkesztette: Budai István és Rácz Andrea

\section{Néhány gyors kérdés Ronald Woodshoz}

Budai István: Milyennek láttad a 30 évvel ezelőtti Magyarországot és a magyar társadalmat? 
Ronald Woods: Számomra nagyon szimpatikus volt a gorbacsovi szellem érzékelése, egyértelmüen világossá vált, hogy ebben a rendszerváltás körüli új helyzetben nagyon is szükség lesz a szociális munkára. Hirtelen sok lett a hajléktalan, erős alkoholproblémák jelentek meg, és nagyon gyorsan láthatóvá vált a kapitalizmussal kapcsolatos emberi naivitás: itt van már a kánaán, és hogy a bécsi Mariahilfer Str.-én élünk. Hamar érzékelhetővé vált a csalódás is, és hogy itt nem a liberális demokrácia fog kialakulni, hanem inkább egy konzervatív szemléletü politika. Nem jó érzéseim voltak a Fidesz álarcával összefüggésben sem, és gyorsan érzékelhetővé vált, hogy megszüntetik a szocializmusban kialakított, elfogadható és funkcionáló jó vívmányokat, azaz ,a vízzel együtt a gyereket is kidobják a lavórból”.

\section{B. I.: Milyen volt az újrainduló magyar szociális szakma?}

R. W.: Meglepődve láttam, hogy egyre többen (ezek között fontos szakemberek és politikacsinálók) kiálltak a szociális munka és szakma szükségessége mellett. Ez nem csupán a gondolatok szintjén jelent meg, hanem a mindennapi gyakorlati cselekvésekben, akciókban, különböző szervezkedésekben, egy nagyon izgalmas, önzetlen és becsületes folyamat és időszak volt. Persze érthető módon voltak viták, amelyek inkább előrébb vitték a folyamatokat. Nem hangzott jól például a szociális munkás kifejezés, többek között valószínűleg a munkás korábbi „proli” kifejezésének áthallásai miatt. A kezdeti szakmai gondolkodás és tevékenységek erös lökést adtak, hogy elinduljanak fejlesztő folyamatok, törvénykezések, az intézményesülés.

\section{B. I.: Hogyan láttad addigi tapasztalataid alapján és a külső szemlélö szemével a magyar szociálismunkás-képzés kezdeteit?}

R. W.: Ott voltam a Soproni Konferencián 1990 februárjában, és az összes alkotó vita eredményeképp érzékelhető volt, hogy minden képzőiskola küzdelmeit méltányolni kell, és tevékenységét el kell fogadni, az iskolák között egyenlőséget és partnerséget kell kialakítani, de az ELTE egy kicsit kiemelkedő, „vezérhajó” szerepet vitt, elsősorban Ferge Zsuzsa személyisége és tevékenysége okán. Jó, hogy ott megszülettek az általános szociálismunkásképzés tantervi rányelvei, ebben fejeződött ki az egység, de a „virágozzék száz virág” elve alapján minden iskola kitalálhatta a saját útját is. Kialakult egy jófajta decentralizácó, mert a helyi problémákra jól reagáló iskolai koncepciók kerültek kimunkálásra.

B. I.: Mit tartottál nagyon fontosnak a magyar szociálismunkás-képzés indulásához, fejlödéséhez?

R. W.: Talán a legfontosabb, hogy a terepgyakorlat jól szervesüljön a képzőfolyamat egészébe. Másrészt a szociálismunkás-képzés ne legyen szociológus- vagy pszichológusképzés, és hogy alapvetően nem akadémiai jellegünek kellene lennie. ${ }^{2}$

\footnotetext{
${ }^{2}$ Ronald Woods korábbi magyarországi tevékenysége során több fontos tanulmányt írt a 90-es évek elején induló, hazai felsőfokú szociálismunkás-képzés szervezői, tanárai és diákjai számára, amelyek a mai napig alapvetően fontosak, meghatározóak és mondandójuk érvényesnek tekinthetők:

Woods, R. (1990): A szociális munka gyakorlatának oktatása. Esély, 5. 44-52.

Woods, R. (1994): A szociális munka tevékenységeinek egy lehetséges rendszerezése. In Hegyesi G. - Talyigás K. (szerk.): A szociális munka elmélete és gyakorlata I. Semmelweis Kiadó. 32-45.
} 


\section{B. I.: Mik voltak a képzésfejlesztés elöremutató mozzanatai a 90-es évek elején?}

R. W.: Szerencsésnek tekinthető és elég gyorsan elfogadottá vált, hogy a gyakornokok tapasztalatszerzéséhez, a képességeik fejlesztéséhez nem elegendő az egy terepen (egy szociális intézményben, szolgáltatásnál) folyó gyakorlat. A négyéves képzésben több szolgáltatást kell megismerni a gyakornokoknak, és fontos több tereptanárral gyakorolni, azaz a képzőfolyamatban minimum négy különböző terepszínhelyre van szükség. Másrészt kockázatos volt, hogy nem szociális munkások, ill. szociálismunkás-diplomával rendelkezők tanították a szakmát, de ez akkor nem is lehetett volna másképp. Már a kezdetekkor látszott egy feszültség, nevezetesen a szociális munkás eléggé közel áll a pszichológiához és a pszichológusokhoz, hiszen sokszor érzésekkel is telítetten, vele hasonlóan kell dolgozni. Másfelől meg a közösséggel vagy az ifjúsággal kell dolgoznia. Az egyik diák inkább preferálja a pszichológiai megközelítéseket és szemléletet, a másik pedig inkább közösségi szellemiséggel bíró aktivitást. Kérdés volt már akkor (és minden bizonnyal azóta is), hogy miképpen lehet ezeket a komponenseket hatékonyan és eredményesen összekapcsolni a képzésben. Hogyan lehet a szociálpszichológiai, szociálpolitikai és közösségi elemeket integrálni egymással.

B. I.: Mostani itt-tartózkodásod tapasztalatai alapján hogy látod a jelenlegi magyar szociálismunkás-képzést?

R. W.: Korábban is és most is alapvető fontosságúnak tartom, hogy miként lehetne a terepgyakorlatokat minőségi módon fejleszteni. Többek között a szervezeti kultúra fejlesztéséhez, az intézményi innovációk alakításához ugyanis kiváló a jól szervezett és minőségi módon folytatott terepgyakorlat.

\section{B. I.: Mik a magyar szociális munka (szakma) számára a legfontosabb veszélyek?}

R. W.: A magyar társadalom nagyon rosszul értelmezi például az időskort és kezeli az időseket. Ez egy nagy veszély is, de ugyanakkor lehetőség is a szociális munka fejlődése szempontjából. Másrészt jó lenne erős szakmai érdekvédelem kialakítása, és az ezeket képviselő egy erős szervezet talán nem rossz példa erre az egyesült államokbeli National Association of Social Work, az Egyesült Királyságban a British Association of Social Workers vagy az Australian Association of Social Workers. Határozott véleményem, hogy a jóléti állam utáni időszakban így Magyarországon is nagyon kellene törekedni az erős szakmai érdekérvényesítésre, amelyet most nem nagyon látok itt, az erőket össze kellene adni és kiállni, kiabálni kell, egy nagyon erős szakmai szervezetre volna szükség és nem túl sok kicsire.

B. I.: Milyen helyet foglal el a magyar szakma és képzés, ha nemzetközi összefüggésekben vizsgálódunk?

R. W.: Igazán jó volt a 30 évvel ezelőtti - igazán történelmi - szituáció: azaz mindenki érezte, hogy együtt vagyunk egy szakmában, van egyfajta egységesség, szakmai identitást lehet építeni. Fontos emberek fontosakat mondanak a társadalom és az egyes ember fejlődése 
érdekében. Akkor úgy nézett ki, hogy e hatás hosszabb távon erősödni fog, sajnos ez ma nem így van.

B. I.: Mely dél-afrikai és ausztráliai szakmai tapasztalataid lennének hasznosithatók Magyarországon?

R. W.: El kell fogadni, hogy a globalizáció megállíthatatlan és a szociális szakmának készülnie kell, hogy a tendencia nem fog megváltozni, azaz egyre gyengébb lesz a jóléti állam, kisebb lesz az állami felelősségvállalás és kisebb szerepe lesz a nonprofit szervezeteknek. Így hát fel van adva a feladat a szakmának, azazhogy mi a helye, szerepe a szociális munkának a gyenge állam időszakában. Az állam kevésbé akar részt vállalni a szociális problémák mélyreható és tartós kezeléséből, csak időleges és tüzoltó megoldásokra vállalkozik. Magyarországon a szociális ellátás feladatát az állam helytelenül egyre inkább eltolja az egyházak és intézményei, de Ausztráliában is a nonprofit, Dél-Afrikában pedig a charity szervezetek irányába. Ha Magyarországon a szociális területet a jövőben az egyház dominálná, akkor a szociális munka igencsak leszükülne, jelentősen csorbítaná vagy teljesen elvesztené az állami felelősséget és a szakmai értékrendjét, utóbbiról tudjuk, hogy nagyon sok ponton nem egyezik az egyházak által közvetítekkel (pl. az egyház képviselői megmondják, hogy mit is csináljon a hívő, ahelyett, hogy együttmüködjenek a szociális problémák kezelésében). Másrészt e szakmában is válaszokat kell adni a klímaváltozásra, amelyre igen hasznos keret továbbra is az ökoszisztéma, továbbá miképpen lehetne green (zöld) szociális munkát folytatni. Érdemes lenne a ma elméleti és gyakorlati szakembereinek önmaguknak is feltenni a kérdést: mi lesz perspektivikusan 2030 év múlva, és mi lesz ebben a szociális munkások szerepe.

A gyorsinterjú 2019. október 23-án készült. Az interjút Budai István készitette és szerkesztette. 